\title{
Pengaruh Model TGT Media Dakonmatika Materi FPB \& KPK Terhadap Hasil Belajar
}

\author{
Zulfa Setiadi ${ }^{*}$, Fenny Roshayanti², Wawan Priyanto ${ }^{3}$ \\ 123 Program Studi Pendidikan Guru Sekolah Dasar, Fakultas Ilmu Pendidikan, Universitas PGRI Semarang.
}

\author{
ARTICLEINFO \\ Article history: \\ Received 18 August 2019 \\ Received in revised form \\ 19 September 2019 \\ Accepted 25 October 2019 \\ Available online 30 \\ November 2019

\section{Kata Kunci:} \\ Teams Game Tournament, \\ Dakonmatika FPB \& KPK, \\ hasil belajar siswa. \\ Keywords: \\ Teams Game Tournament, \\ FPB \& KPK Dakonmatika, \\ student learning outcomes.
}

\begin{abstract}
A B S T R A K
Tujuan yang dicapai ialah Bagaimana pengaruh model TGT media Dakonmatika materi FPB dan KPK terhadap hasil belajar siswa kelas IV SD N 01 Candi Semarang. Jenis penelitian ini adalah penelitian kuantitatif. Desain penelitian yang digunakan dalam penelitian ini adalah Pre-Eksperimental Design dengan bentuk One Grup Pretest-Posttest Design. Populasi penelitian ini adalah seluruh siswa kelas IV SD N 01 Candi Semarang. Sampel yang diambil adalah siswa dari kelas IV SD N 01 Candi Semarang yang berjumlah 20 orang dengan menggunakan teknik Non Probability Sampling yang merupakan jenis sampling jenuh. Data dalam penelitian ini diperoleh melalui tes, dokumentasi dan wawancara. Hasil belajar siswa kelas IV menggunakan model TGT media Dakonmatika materi FPB dan KPK,, diperoleh nilai rata-rata pretest sebesar 40,8 dengan nilai tertinggi 68 dan nilai terendah 28 . Nilai rata-rata posttest sebesar 78 dengan nilai tertinggi 92 dan nilai terendah 68. Berdasarkan hasil perhitungan data akhir nilai posttest diperoleh $L_{\text {hitung }}=0,98$ dengan $n=20$ dan taraf nyata $\alpha=0,05$ atau $5 \%$ dari daftar nilai kritis $L$ didapat $L_{\text {tabel }}=0,190$, karena $L_{\text {hitung }}<L_{\text {tabel }}$ yaitu $0,98<0,190$ maka $\mathrm{H}_{0}$ diterima, sehingga dapat disimpulkan bahwa bahwa sampel berasal dari populasi berdistribusi normal. Dari data hasil pretest dan posttest memenuhi kriteria pengujian karena keduanya berdistribusi normal . Berdasarkanuji- $t$ diperoleh $t_{\text {hitung }}>t_{\text {tabel }} y$ aitu 139,45 $>2,086$. Dengan demikian $\mathrm{H}_{0}$ ditolak dan $\mathrm{H}_{a}$ diterima.
\end{abstract}

A B S T R A C T

. The goal achieved is how the influence of the TGT media Dakonmatika media on FPB and KPK material on the learning outcomes of fourth grade students of SD N 01 Candi Semarang.This type of research is quantitative research. The research design used in this study was PreExperimental Design in the form of One Group Pretest-Posttest Design. The population of this research is all grade IV students of SD N 01 Candi Semarang. The sample taken was students from class IV SD N 01 Candi Semarang, amounting to 20 people using the Non Probability Sampling technique which is a type of saturated sampling. Data in this study were obtained through tests, documentation and interviews. Class IV student learning outcomes using the TGT model of media Dakonmatika FPB and KPK material, obtained an average pretest score of 40.8 with the highest value of 68 and the lowest value of 28 . The average posttest score of 78 with the highest value of 92 and the lowest value of 68 Based on the results of the final data calculation the posttest value is obtained Lhitung $=0.98$ with $n=20$ and the real level $\alpha=0.05$ or $5 \%$ of the list of critical values $L$ is obtained Ltable $=0.190$, because Lhitung $<$ Ltable is $0.98<0.190$ then $\mathrm{H} 0$ is accepted, so it can be concluded that the sample comes from normally distributed populations. From the data the results of the pretest and posttest meet the test criteria because they are normally distributed. Based on the t-test obtained $t$ count $>\mathrm{t}$ table, namely $139.45>2.086$. Thus $\mathrm{HO}$ is rejected and Hadit accept.

\footnotetext{
${ }^{1}$ Corresponding author.

E-mail addresses: zlfsetiadi@gmail.com (Zulfa Setiadi)
} 


\section{Pendahuluan}

Pendidikan merupakan hal terpenting dalam kehidupan, apalagi dalam era globalisasi sekarang ini. Seseorang yang menempuh pendidikannya dengan baik akan terlihat kesungguhannya dalam kesehariannya. Pendidikan tidak hanya dilakukan di dalam ruangan dengan seorang pendidik dan yang di didik, tetapi dapat dilakukan dimananpun dan kapanpun, agar mewujudkan proses pembelajaran didik secara aktif dan mengembangkan potensi dirinya. Sukmadinata (2009:3) mengungkapkan bahwa "pendidikan pada dasarnya merupakan interaksi antara pendidik dengan peserta didik, untuk mencapai tujuan pendidikan, yang berlangsung dalam lingkungan tertentu". Menurut Purwanto (2003:10) pendidikan ialah "pimpinan yang diberikan dengan sengaja oleh orang dewasa kepada anak-anak, dalam pertumbuhannya (jasmani dan rohani) agar berguna bagi diri sendiri dan bagi masyarakat".

Undang-Undang No.20 Tahun 2003 Pasal 1 Ayat 1 mengungkapkan bahwa : Pendidikan adalah usaha sadar dan terencana untuk mewujudkan suasana belajar dan proses pembelajaran agar peserta didik secara aktif mengembangkan potensi dirinya untuk memiliki kekuatan spiritual keagamaan, pengendalian diri, kepribadian, kecerdasan, akhlak mulia, serta keterampilan yang diperlukan dirinya, masyarakat, bangsa dan Negara. Pendidikan hal yang sangat penting dan mempunyai berbagai komponen pendukung. Komponen-komponen tersebut yaitu siswa, guru, materi, sarana, hasil belajar, lingkungan dan pengelolaan. Komponen tersebut jika dijalankan dengan selaras maka dapat dikatakan dengan pendidikan yang berhasil. Peraturan pemerintah Republik Indonesia nomor 19 tahun 2005 tentang Standar Nasional Pendidikan bab VII pasal 42 ayat 1 mengemukakan bahwa :

Setiap satuan pendidikan wajib memiliki sarana yang meliputi perabot, peralatan pendidikan, media pendidikan, buku dan sumber belajar lainnya, bahan habis pakai, serta perlengkapan lain yang memerlukan untuk menunjang proses pembelajaran yang teratur dan berkelanjutan.

Dari beberapa komponen tersebut salah satu bagian penting adalah sarana yang menekankan pada media pembelajaran. Media pembelajaran secara umum adalah alat bantu proses belajar mengajar. Segala sesuatu yang dapat dipergunakan untuk merangsang pikiran, perasaan, perhatian dan kemampuan atau ketrampilan pebelajar sehingga dapat mendorong terjadinya proses belajar. Menurut Bapak Slamet Haryadi, S.Pd. salah seorang guru di SD N 01 Candi Semarang, pembelajaran yang dilaksanakan di SD tersebut kurang efektif karena jarang sekali menggunakan media pembelajaran, sehingga penyampaian materi kurang jelas atau nyata dan kurang menarik. Sedangkan menurut Ibu Tri Jumiyati, S.Pd siswa belum cukup memahami materi jika tidak menggunakan media pembelajaran, siswa akan lebih bersemangat dan lebih mengerti jika pembelajarannya dicontohkan dengan hal yang nyata.

Salah satu materi matematika yaitu FPB \& KPK mulai di dapat siswa Sekolah Dasar saat duduk di kelas IV atau V. Faktorisasi prima, Kelipatan Persekutuan Terkecil (KPK) dan Faktor Persekutuan Terbesar (FPB) merupakan pengembangan dari operasi bilangan, yaitu penjumlahan, pengurangan, perkalian, dan pembagian. Faktorisasi prima dapat digunakan untuk mencari FPB \& KPK. Pada dasarnya, materi FPB \& KPK cukup mudah untuk dipelajari asalkan memahami konsepnya. Apalagi banyak juga kegiatan sehari-hari yang dapat diselesaikan dengan konsep FPB \& KPK. Upaya untuk mengatasi permasalahan pada proses pembelajaran FPB \& KPK, dapat digunakan model pembelajaran Teams Game Tournament dengan media dakonmatika. Teams Game Tournament adalah suatu tipe pembelajaran kooperatif yang menempatkan siswa dalam kelompok belajar yang beranggotakan 4 sampai 6 orang siswa yang memiliki kemampuan, jenis kelamin, suku kata atau ras yang berbeda. Media permainan tradisional dakon ialah berasal dari kata dhaku dan mendapat akhiran an. Dhaku berarti mengaku bahwa sesuatu itu miliknya. Jadi dalam permainan ini dikandung tujuan bahwa si pemain berusaha mengaku bahwa sesuatu itu adalah miliknya. Permainan Dakon adalah betul-betul murni permainan ank-anak. Permainan berlatar kehidupan bertani. Digambarkan bagaimana lumbung. Sawah yang tidak digunakan dinamakan bera. Sawah yang hasilnya sangat kurang dinamakan ngacang nandur kacang. Jadi permainan ini bersifat mendidik bagaimana cara mengelola rumah tangga yang baik. Cara hidup berumah tangga yang baik haruslah hemat, ulet, dan teliti.

Dari kesimpulan wawancara dengan guru, peneliti mengambil beberapa masalah yaitu : 1. Masih ada guru yang mengajar hanya menggunakan metode ceramah. 2. Kurangnya penggunaan media dalam pembelajaran. 3. Pembelajaran yang kurang menarik. 4. Siswa kurang minat dalam pembelajaran.

Langkah yang dapat dilakukan untuk mengatasi masalah tersebut adalah setiap pembelajaran agar ada media yang digunakan, sehingga pembelajaran jadi lebih jelas dan nyata, lebih interaktif, efisien dalam waktu dan tenaga, meningkatkan kualitas hasil belajar, proses belajar dapat dilakukan dimana saja dan kapan saja, dan megubah guru serta murid menjadi lebih aktif dan produktif. Berdasarkan permasalahan tersebut peneliti mempunyai tujuan untuk mengetahui pengaruh model TGT media dakonmatika materi FPB dan KPK terhadap hasil belajar siswa kelas IV SD N 01 Candi Semarang. 
Belajar sangat penting bagi kehidupan, dengan belajar kita dapat mengetahui apa yang belum kita ketahui. Belajar bisa diartikan sebagai semua aktivitas mental atau psikis yang dilakukan oleh seseorang sehingga menimbulkan perubahan tingkah laku yang berbeda antara sesudah belajar dan sebelum belajar. Yaitu berusaha memperoleh kepandaian atau ilmu, berlatih, berubah tingkah laku atau tanggapan yang disebabkan oleh pengalaman. Belajar bisa juga didefinisikan sebagai sebuah proses perubahan di dalam keperibadian manusia dan perubahan tersebut ditampakkan dalam bentuk peningkatan kualitas dan kuantitas tingkah laku seperti peningkatan kecakapan, pengetahuan, sikap, kebiasaan, pemahaman, keterampilan, daya pikir dan kemampuan-kemampuan yang lain, suatu proses didalam kepribadian manusia, perubahan tersebut ditempatkan dalam bentuk peningkatan kualitas dan kuantitas. Kegiatan belajar biasa dilakukan di sekolah, di rumah, dan di tempat lain seperti di museum, di laboratorium, di hutan dan dimana saja.

Slameto (2003:2) menyatakan bahwa "belajar ialah suatu proses usaha yang dilakukan seseorang untuk memperoleh suatu perubahan tingkah laku yang baru secara keseluruhan, sebagai hasil pengalamannya sendiri dalam interaksi dengan lingkungannya".

Gagne dalam Mudjiono (2009:10) mengungkapkan belajar pada hakikatnya merupakan "kegiatan yang kompleks. Hasil belajar berupa kapabilitas. Setelah belajar memiliki keterampilan, pengetahuan, sikap, dan nilai. Hal tersebut timbul stimulasi dari lingkungan dan proses kognitif yang dilakukan oleh pembelajar.

Hamalik (2009:27) mengatakan belajar adalah "modifikasi atau memperteguh kelakuan melalui pengalaman. Suatu proses kegiatan dan bukan hasil atau tujuan. Belajar bukan hanya mengingat, akan tetapi lebih luas dari itu yakni mengalami. Hasil belajar bukan suatu penguasaan hasil latihan melainkan pengubahan kelakuan".

Berdasarkan beberapa pengertian di atas dapat di simpulkan bahwa pengertian belajar adalah suatu proses memperoleh pengetahuan dan pengalaman dalam wujud perubahan tingkah laku dan kemampuan beraksi yang relatif permanen atau menetap karena adanya interaksi individu dengan lingkungan dan dunia nyata. Melalui proses belajar seseorang akan memiliki pengetahuan, keterampilan, dan sikap yang lebih baik

Menurut Suprijono (2012:5), hasil belajar adalah polapola perbuatan, nilai-nilai, pengertianpengertian, sikapsikap, apresiasi dan keterampilan. Selanjutnya Supratiknya (2012:5) mengemukakan bahwa hasil belajar yang menjadi objek penilaian kelas berupa kemampuan-kemampuan baru yang diperoleh siswa setelah mereka mengikuti proses belajar-mengajar tentang mata pelajaran tertentu. Dalam sistem pendidikan nasional rumusan tujuan pendidikan mengacu pada klasifikasi hasil belajar dari Bloom yang secara garis besar yaitu aspek kognitif, aspek afektif dan aspek psikomotor (Widodo, 2013).

Siswa SD umurnya berkisar antara 6 atau 7 tahun, sampai 12 atau 13 tahun, mereka berada pada fase operasional konkret. Kemampuan yang tampak pada fase ini adalah kemampuan dalam proses berfikir untuk mengoperasikan kaidah-kaidah logika, meskipun masih terkait dengan objek yang bersifat konkret, Piaget dalam Heruman (2014:1)

Sedangkan menurut Heruman (2014:2) konsep-konsep pada kurikulum matematika SD dapat dibagi menjadi 3 kelompok besar, yaitu pemahaman konsep dasar (penanaman konsep), pemahaman konsep, dan pembinaan keterampilan.

Model pembelajaran adalah suatu perencanaan atau suatu pola yang digunakan sebagai pedoman dalam merencanakan pembelajaran dalam tutorial dan untuk menentukan perangkat-perangkat pembelajaran termasuk di dalamnya buku-buku, film, komputer, kurikulum, dan lain-lain. Joyce dalam Trianto (2007:5)

Adapun Soekamto, et. al dalam Trianto (2007:5) mengemukakan maksud dari model pembelajaran adalah: "kerangka konseptual yang melukiskan prosedur yang sistematis dalam mengorganisasikan pengalaman belajar untuk mencapai tujuan belajar tertentu, dan berfungsi sebagai pedoman bagi para perancang pembelajaran dan para pengajar dalam merencanakan aktivitas belajar mengajar".

Teams Games Tournament merupakan salah satu strategi pembelajaran kooperatif yang dikembangkan oleh Slavin dalam Huda, (2014:197) untuk membantu siswa mereview dan menguasai materi pelajaran. Slavin mengemukakan bahwa TGT berhasil meningkatkan skill-skill dasar, pencapaian, interaksi positif antar siswa, harga diri, dan sikap penerimaan pada siswa-siswa lain yang berbeda.

Dalam TGT, siswa mempelajari materi di ruang kelas. Setiap siswa ditempatkan dalam satu kelompok yang terdiri dari 3-5 orang berkemampuan rendah, sedang, dan tinggi. Dalam TGT setiap anggota ditugaskan untuk mempelajari materi terlebih dahulu bersama anggota-anggotanya, barulah mereka di uji secara individual melalui game akademik. Nilai yang mereka peroleh dari game akan menentukan skor kelompok mereka masing-masing, Huda (2014:197).

Menurut Slavin dalam Rusman(2014:225) karakteristik yang terdapat dalam pembelajaran TGT adalah sebagai berikut: 
1) Siswa bekerja dalam kelompok-kelompok kecil.

2) Games Tournament.

3) Penghargaan kelompok.

Dalam pembelajaran kontekstual, program pembelajaran lebih merupakan rencana kegiatan kelas yang dirancang guru. Dalam program tercermin tujuan pembelajaran, media pembelajaran, langkahlangkah pembelajaran, dan authentic assessment-nya. Dalam konteks tersebut, program yang dirancang guru benar-benar rencana pribadi tentang apa yang akan dikerjakannya bersama siswa.

Menurut Shoimin (2014:205) "sebelum melaksanakan pembelajaran dengan menggunakan TGT, guru tentu saja terlebih dahulu membuat desain (skenario) pembelajaran". Desain pembelajaran dengan menggunakan TGT sebagai berikut:

\section{1) Penyajian Kelas}

Pada awal pembelajaran, guru menyampaikan materi dalam penyajian kelas atau sering disebut dengan presentasi kelas (class presentations). Guru menyampaikan tujuan pembelajaran, pokok materi, dan penjelasan singkat tentang LKS yang dibagikan kepada kelompok. Kegiatan ini biasanya dilakukan dengan pengajaran langsung atau dengan ceramah yang dipimpin oleh guru.

\section{2) Belajar dalam Kelompok (Teams)}

Guru membagi kelas menjadi kelompok-kelompok berdasarkan kriteria kemampuan (prestasi) peserta didik dari ulangan harian sebelumnya, jenis kelamin, etnik, dan kelompok. Fungsi kelompok adalah untuk lebih mendalami materi bersama teman kelompoknya dan lebih khusus untuk mempersiapkan anggota kelompok agar bekerja dengan optimal pada saat game atau permainan.

\section{3) Permainan (Games)}

Game atau permainan terdiri dari pernyataan-pernyataan yang relevan dengan materi, dan dirancang untuk menguji pengetahuan yang didapat peserta didik dari penyajian kelas dan belajar kelompok. Kebanyakan game atau permainan terdiri pernyataan-pernyataan sederhana bernomor.

\section{4) Pertandingan atau Lomba (Tournament)}

Tournament atau lomba adalah struktur belajar, dimana game atau permainan terjadi. Biasanya tournament atau lomba dilakukan pada akhir minggu atau pada setiap unit setelah guru melakukan presentasi kelas dan kelompok sudah mengerjakan lembar kerja peserta didik.

\section{5) Penghargaan Kelompok (Team Recognition)}

Setelah turnamen atau lomba berakhir, guru kemudian atau kelompok yang menang, masingmasing tim atau kelompok akan mendapatkan sertifikat atau hadiah apabila rata-rata skor memenuhi kriteria yang telah ditentukan.

A. Kelebihan dan Kekurangan TGT Menurut Shoimin (2014:207) yang merupakan kelebihan dari pembelajaran TGT antara lain:

a) Model TGT tidak hanya membuat peserta didik yang cerdas (berkemampuan akademis tinggi) lebih menonjol dalam pembelajaran, tetapi peserta didik yang berkemampuan akademi lebih rendah juga ikut aktif dan mempunyai peranan penting dalam kelompoknya.

b) Dengan model pembelajaran ini, akan menumbuhkan rasa kebersamaan dan saling menghargai sesama anggota kelompoknya.

c) Dalam model pembelajaran ini, membuat peserta didik lebih bersemangat dalam mengikuti pelajaran. Karena guru menjanjikan sebuah penghargaan.

d) Dalam pembelajaran peserta didik ini, membuat peserta didik menjadi lebih senang dalam mengikuti pelajaran karena ada kegiatan permainan berupa turnamen.

B. Kelemahan TGT yaitu:

a) Membutuhkan waktu lama.

b) Guru dituntut untuk pandai memilih materi pelajaran yang cocok untuk model ini.

c) Guru harus mempersiapkan model ini dengan baik sebelum diterapkan. Misalnya, membuat soal untuk setiap meja turnamen atau lomba, dan guru harus tau urutan akademis peserta didik dari yang tertinggi hingga terendah. Arsyad (2014:3) mengemukakan "kata media berasal dari bahasa latin medius yang secara harfiah berarti 'tengah', 'perantara' atau 'pengantar pesan dari pengirim kepada penerima pesan". Gerlach \& Ely dalam Arsyad (2014:3) mengatakan bahwa "media apabila 
dipahami secara garis besar adalah manusia, materi, atau kejadian yang membangun kondisi, yang membuat siswa mampu memperoleh pengetahuan, keterampilan, atau sikap".

Fleming dalam Arsyad (2014:3) menyatakan bahwa media adalah "penyebab atau alat yang turut campur tangan dalam dua pihak dan mendamaikannya". Heinich et. aldalam Arsyad (2014:3) berpendapat bahwa "istilah medium sebagai perantara yang mengantar informasi antara sumber dan penerima". Dari pengertian tersebut dapat disimpulkan secara umum pengertian media adalah alat yang digunakan untuk menyalurkan informasi dari sumber ke penerima. Dalam hal ini dapat ditarik kesimpulan bahwa pengertian media pembelajaran sebagai sarana untuk memberikan informasi dalam bentuk pengetahuan yang berasal dari mana saja.

Bermain merupakan sebuah kegiatan yang sangat akrab dengan kehidupan manusia. Pada saat-saat manusia berada dalam proses pembentukan diri dari kanak-kanak menuju dewasa tidak satupun diantara induvidu manusia yang tidak mengenal"Permainan".

Permainan-permainan yang berkembang pada masyarakat sekarang ini merupakan permainan baru, yang tanpa disadari telah merasuk jauh dalam kehidupan bermain anak-anak sehingga dapat menjauhkan anak-anak dari hubungan-hubungan perkawanan yang personal ke impersonal. Juga menyebabkan menipisnya orientasi wawasan anak komunalistik ke induvidualistik.

Definisi "permainan" yang banyak dianut oleh para pakar adalah yang dilontarkan oleh Huizinga (dalam Homo Ludens, 1955) berupaya untuk mengungkapkan ciri atau sifat "bermain" dalam kegiatan manusia dengan mendefinisikan play, bermain, dolanan, sebagai: (a) suatu persiapan untuk menjadi dewasa (b) suatu pertandingan, yang akan menghasilkan yang kalah dan yang menang; (c) perwujudan dari rasa cemas dan marah; (d) suatu hal yang tidak sangat penting dalam masyarakat.

"Permainan" perlu diketahui nilai pendidikannya, dan lebih dari itu juga hubungannya dengan fungsinya untuk "preparation for economic skills", pembekalan keterampilan-keterampilan ekonomi (malinowski, 1960:170). Permainan juga merupakan sebagian dari kondisi-kondisi yang memungkinkan si anak melakukan "objectivication of the self"( Mead, 1934 ). Melalui kegiatan bermain anak-anak akan dapat membayangkan dirinya berada dalam berbagai kedudukan dan peran, dan dengan demikian dia akan dapat membangun karakternya. Dalam bermain, seorang anak harus memperhatikan anak-anak yang lain yang berbeda perannya, tetapi berinteraksi dengannya. Menurut Mead (1934 : 159), "ketika si anak mulai dapat berperilaku sebagai orang lain maka dia sedang berada dalam proses menjadi "an organic memberof society".

Permainan tradisional anak-anak Jawa banyak mengandung nilai-nilai budaya tertentu serta mempunyai fungsi melatih permainannya melakukan hal-hal yang akan penting nantinya bagi kehidupan mereka di tengah masyarakat, sepeti nantinya bagi kehidupan masyarakat, seperti misalnya melatih cakap hitung menghitung, melatih kecakapan berfikir, melatih bandel (tidak cengeng), melatih keberanian, melatih bersikap jujur dan sportif dan sebagainya, Tashadi (1993: 57-59).

Permainan tradisional dakon berasal dari kata dhaku dan mendapat akhiran an. Dhaku berarti mengaku bahwa sesuatu itu miliknya. Jadi dalam permainan ini dikandung tujuan bahwa si pemain berusaha mengaku bahwa sesuatu itu adalah miliknya. Permainan Dhakon adalah betul-betul murni permainan anak-anak. Permainan berlatar kehidupan bertani. Jadi disini digambarkan bagaimana lumbung. Sawah yang tidak digunakan dinamakan bera. Sawah yang hasilnya sangat kurang dinamakan ngacang nandur kacang. Permainan ini bersifat mendidik bagaimana cara mengelola rumah tangga yang baik. Cara hidup berumah tangga yang baik haruslah hemat, ulet, dan teliti.

Pemain dhakon berjumlah dua orang. Permainan ini melatih anak untuk ulet, hemat, dan teliti. Anak dilatih untuk selalu megejar untung dan menabung di lumbung. Lubang untuk sawah terdiri dari dua baris, masing masing berjumlah 5, 7, 9, atau 11, dan terletak diantara dua lumbung, lubang untuk sawah lebih kecil daripada lubang untuk lumbung, sedangkan untuk isinya dapat digunakan benik (buah baju), kecik (biji sawo). Roshayantiet.al (2013: 131)

Pada taraf usia anak SD mereka masih berfikir secara kongkrit sehingga dengan pembelajaran yang menggunakan media visual akan dapat memudahkan siswa untuk memahami materi yang disampaikan. Selain itu dengan media ini maka dapat menarik perhatian dan menyenangkan bagi siswa sehingga pembelajaran matematika tidak membosankan dan lebih variatif.

Heruman (2014: 1) mengemukakan bahwa "siswa Sekolah Dasar (SD) umurnya berkisar antara 6 atau 7 tahun, sampai 12 atau 13 tahun. Menurut Piaget, mereka berada pada fase operasional konkret. Kemampuan yang tampak pada fase ini adalah kemampuan dalam proses berpikir untuk mengoperasikan kaidah-kaidah logika, meskipun masih terikat dengan objek yang bersifat konkret".

Ruseffendi dalam Heruman(2014: 1) Matematika adalah "bahasa simbol ilmu deduktif yang tidak menerima pembuktian secara induktif, ilmu tentang pola keteraturan, dan struktur yang terorganisasi, 
mulai dari unsur yang tidak di definisikan, ke unsur yang di definisikan, ke asioma atau postulat dan akhirnya ke dalil".

Sedangkan hakekat matematika menurut Soedjadi dalam Heruman (2014: 1) yaitu "memiliki objek tujuan abstrak, bertumpu pada kesepakatan, dan pola pikir yang deduktif".

Pelajaran matematika pada umumnya gampang-gampang susah, tergantung pada diri kita ingin terus mencobanya hingga berhasil atau menyerah begitu saja. Memang kemampuan sesorang berbeda dan ada batasnya, ada yang baik, ada yang sedang, bahkan ada yang kurang. Faktor tersebut ada dua macam yaitu dari dalam yang berkaitan dengan diri sendiri atau kemampuan kognitif anak, dan faktor dari luar yang berkaitan dengan lingkungan. Penyampain pembelajaran guru juga bisa dikatakan faktor lain, biasanya guru mengajar dengan media yang menarik maka membangkitkan gairah siswa untuk giat belajar.

Berikut adalah kegunaan dari KPK dan FPB sehingga harus dibahas dalam dunia matematika. Sebelumya, segala sesuatu yang kita pelajari di dunia ini pasti memiliki manfaatnya tersendiri bagi kehidupan kita. Selain itu dengan konsep KPK dan FPB ini dapat mengajari kita untuk berlaku adil dalam setiap tindakan. Misalnya, untuk membagi sejumlah buah apel dan jeruk yang berbeda kepada saudara dengan porsi yang sama. Dan masih banyak contoh lain dalam penerapan KPK dan FPB yang berguna bagi kehidupan kita.

\section{Metode}

Penelitian mengenai pengaruh permainan dakon dalam pembelajaran matematika materi fpb dan kpk terhadap hasil belajar siswa kelas IV akan dilaksanakan di SD N 01 Candi Semarang, penelitian tersebut dilaksanakan pada bulan oktober tahun ajaran 2018/2019. Dalam penelitian ini peneliti menggunakan dua variabel yang terdiri dari variabel bebas dan variabel terikat. Variabel bebas atau variabel X dalam penelitian ini adalah model TGT media dakonmatika materi FPB \& KPK, sedangkan Variabel terikat atau variabel Y dalam penelitian ini adalah hasil belajar siswa kelas VI menggunakan model TGT media dakonmatika materi FPB \& KPK.

Desain penelitian ini menggunakan desain penelitian pre-eksperimental designs dengan bentuk OneGroup-Pretest-Posttest Design yang terdapat Pretest sebelum di berikan perlakuan dengan Posttest sesudah di berikan perlakuan. Dengan demikian hasil penelitian dapat di ketahui lebih akurat, karena dapat membandingkan keadaan sebelum di beri perlakuan dan sesudah di beri perlakuan.

Desain ini juga sering di sebut sebagai eksperimen semu. Karena masih terdapat variabel luar yang ikut berpengaruh terhadap terbentuknya variabel dependen. Hal ini dapat terjadi karena tidak adanya variabel kontrol dan sampel yang tidak di pilih secara random.

Populasi penelitian adalah wilayah generalisasi yang terdiri atas objek/subjek yang mempunyai kualitas dan karakteristik tertentu yang ditetapkan oleh peneliti untuk dipelajari dan kemudian di tarik kesimpulan, Sugiyono (2015: 117). Sebagai populasi yang direncanakan dalam penelitian ini adalah siswa kelas VI di SD N01 Candi Semarang yang berjumlah 20 siswa.

Sampel penelitian ini adalah bagian dari jumlah dan karakteristik yang dimiliki oleh populasi tersebut, Sugiyono (2015: 118). Dari populasi tersebut, diambil sampel yaitu kelas VI yang terdiri dari 20 siswa dan ditetapkan sebagai kelas eksperimen yang mendapatkan pembelajaran dengan model TGT media dakonmatika materi FPB \& KPK.

Teknik sampling merupakan teknik pengambilan sampel, Sugiyono (2015: 118-119). Dalam penelitian ini, peneliti menggunakan sampling jenuh. Sampling jenuh adalah teknik penentuan sampel apabila semua anggota populasi digunakan sebagai sampel.

Teknik pengumpulan data merupakan langkah yang paling utama dalam melakukan penelitian, karena tujuan utama dalam penelitan adalah mendapatkan data. Tanpa mengetahui teknik pengumpulan data, maka peneliti tidak akan mendapatkan data yang memenuhi standar data yang di tetapkan, Sugiyono (2015: 193). Dalam penelitian ini peneliti menggunakan metode tes dan non tes.

\section{Hasil dan Pembahasan}

\section{Analisis Data Awal}

Analisis data awal dilakukan untuk mengetahui hasil data awal Pretest pada kelas IV. Pada data ini akan melakukan Uji Normalitas. Data hasil peneitian dilakukan uji normalitas dengan menggunakan uji liliefors untuk mengetahui data berasal dari populasi yang berdistribusi normal atau tidak. Uji normalitas dilakukan pada nilai Pretest siswa dengan hipotesis sebagai berikut. 
Tabel 1. Normalitas Awal (Nilai Pretest)

\begin{tabular}{lllcc}
\hline Kelas & $\mathrm{N}$ & $\mathrm{L}_{0}$ & $\mathrm{~L}_{\text {tabel }}$ & Kesimpulan \\
\hline Responden & 20 & 0,99 & 0,195 & Berdistribusi Normal \\
\hline
\end{tabular}

Kesimpulan : $\mathrm{L}_{0}<$ Ltabel maka $\mathrm{H}_{0}$ diterima artinya data berdistribusi normal. Berdasarkan data hasil perhitungan yaitu uji normalitas Pretest pada kelas IV didapatkan nilai $L_{\text {hitung }}$ sebesar 0,99 sedangkan $\mathrm{L}_{\text {tabel }}$ 0,195. Berarti $\mathrm{L}_{\text {hitung }} 0,99<\mathrm{L}_{\text {tabel }} 0,195$ maka $\mathrm{H}_{0}$ diterima. Hal ini berarti sampel berasal dari populasi berdistribusi normal.

\section{Analisis Data Akhir}

Analisis data akhir dilakukan untuk mengetahui hasil data akhir Posttest pada kelas IV. Pada data ini akan melakukan Uji Normalitas. Data hasil penelitian dilakukan uji normalitas dengan menggunakan uji liliefors untuk mengetahui data berasala dari populasi yang berdistribusi normal atau tidak. Uji normalitas dilakukan pada nilai Posttest siswa dengan hipotesis sebagai berikut:

Tabel 2. Normalitas Akhir (Nilai Postest)

\begin{tabular}{clrll}
\hline Kelas & $\mathrm{N}$ & $\mathrm{L}_{0}$ & $\mathrm{~L}_{\text {tabel }}$ & \multicolumn{1}{c}{ Kesimpulan } \\
\hline Responden & 20 & 0.98 & 0,190 & Berdistribusi Normal \\
\hline
\end{tabular}

Kesimpulan : $\mathrm{L}_{0}<\mathrm{L}_{\text {tabel }}$ maka $\mathrm{H}_{0}$ diterima artinya data berdistribusi normal. Berdasarkan hasil perhitungan normalitas yaitu uji normalitas Posttest pada kelas IV didapatkan nilai $\mathrm{L}_{\text {hitung }}$ sebesar 0,98 dengan harga $\mathrm{L}_{\text {tabel }}=0,190$. Berarti $\mathrm{L}_{\text {hitung }} 0,98<\mathrm{L}_{\text {tabel }} 0,190$ maka $\mathrm{H}_{\mathrm{a}}$ diterima. Hal ini berarti sampel berasal dari populasi berdistribusi normal.

\section{Uji Hipotesis}

Berdasarkan data hasil Pretest dan Posttest siswa kelas IV SD N 01 Candi Semarang sebagai subjek penelitian dilakukan perhitungan untuk menganalisis hasil Pretest dan Posttest. Pengujian Hipotesis berdasarkan hasil Pretest dan Posttest sebagai berikut :

Tabel 3. Data Hasil Belajar

\begin{tabular}{|c|c|c|}
\hline $\mathrm{N}$ & $t_{\text {hitung }}$ & $t_{\text {tabel }}$ \\
\hline 20 & 139,45 & 2,09 \\
\hline
\end{tabular}

Berdasarkan perhitungan Tabel 3 diperoleh $t_{\text {hitung }}$ sebesar 139,45 sedangkan $t_{\text {tabel }} 2,09$ dengan db = $\mathrm{N}-1=20-1=19$, dan taraf signifikan sebesar 0,05. Karena $t_{\text {hitung }}>t_{\text {tabel }}$ yaitu $139,45>2,09$ maka $\mathrm{H}_{0}$ ditolak dan $\mathrm{H}_{\mathrm{a}}$ diterima. Sehingga dapat dikatakan bahwa model pembelajaran Teams Game Tournament dengan media Dakonmatika berpengaruh terhadap hasil belajar Matematika siswa kelas IV SDN 01 Candi Semarang.

Berdasarkan hasil pretest dan posttest, peningkatan kemampuan siswa sebelum dan sesudah diberi perlakuan dapat dihitung dengan uji gain. Uji gain dapat dilihat pada tabel berikut:

Tabel 4. Data Hasil Pretest-Posttest N-Gain Score

\begin{tabular}{llll}
\hline Pretest & Posttest & Peningkatan & Keterangan \\
\hline 40,8 & 78 & 0,63 & Sedang \\
\hline
\end{tabular}

Dari Tabel 4 persentase peningkatan hasil belajar siswa menunjukkan bahwa pembelajaran ratarata sebelum diberi perlakuan adalah 40,8 dan rata-rata sesudah diberi perlakuan adalah 78 . Hasil perhitungan uji gain hasil belajar siswa meningkat 0,63 dengan keterangan sedang.

Model dan media pembelajaran memang seharusnya diberikan guru kepada siswa. Kejenuhan dalam pembelajaran yang hanya dengan ceramah dapat diminimalisir dengan menggunakan berbagai model dan media pembelajaran yang baru. Penggunaan model dan media pembelajaran tersebut tentunya akan dapat menarik perhatian siswa dalam menerima pembelajaran di kelas. Contohnya model pembelajaran Teams Game Tournament dengan media Dakonmatika yang dapat menjadikan siswa lebih aktif selama mengikuti pembelajaran di kelas. Terlebih lagi pada pembelajaran Matematika yang dekat 
dengan kehidupan keseharian siswa, sehingga media Dakonmatika dapat mendukung pembelajaran untuk menumbuhkan semangat dan minat belajar siswa.

Kejenuhan pada siswa dapat dilihat dari hasil belajar yang kurang maksimal. Masih banyak siswa di SDN 01 Candi Semarang yang mendapatkan nilai Matematika dibawah Kriteria Ketuntasan Minimal (KKM) yaitu sebesar 68. Hal ini dikarenakan guru saat mengajar masih menggunakan metode ceramah dan belum menerapkan variasi pembelajaran yang lebih menarik.

Model pembelajaran Teams Game Tournament merupakan model pembelajaran kooperatif yang dikembangkan oleh Slavin dalam Huda, (2014:197) untuk membantu siswa mereview dan menguasai materi pelajaran, selain itu dapat meningkatkan skill-skill dasar, pencapaian, interaksi positif antar siswa, harga diri, dan sikap penerimaan pada siswa-siswa lain yang berbeda. Sedangkan media Dakonmatika merupakan media yang dibuat untuk membantu siswa lebih aktif dan menumbuhkan semangat dan ingatan siswa lebih mendalam dikarenakan munculnya motivasi untuk senantiasa mencoba menemukan jawaban dari soal fpb \& kpk dengan menjalankan Dakonmatika.

Untuk itu, peneliti melakukan penelitian di SDN 01 Candi Semarang tahun pelajaran 2018/2019. Sampel dalam penelitian ini diambil dengan non probability sampling dengan jenis sampling jenuh. Dalam penelitian ini subyek penelitian adalah siswa kelas IV dengan jumlah siswa 20 siswa. Penelitian ini menggunakan desain penelitian Pre-Experimental Desain dengan bentuk One Group Pretest-Posttest Design. Hasil yang baik adalah apabila nilai Posttest lebih besar dari Pretest.

Berdasarkan hasil analisis uji coba instrumen dengan mempertimbangkan validitas, reliabilitas, tingkat kesukaran, dan daya pembeda maka didapatkan 25 soal memenuhi kriteria dari 45 soal uji coba instrumen. Kemudian dipilih 25 dari 25 soal uji coba yang memenuhi kriteria tersebut digunakan untuk Pretest dan juga Posttest.

Data awal penelitian menggunakan data dari nilai Pretest siswa. Rata-rata nilai Pretest yaitu sebesar 40,8. Berdasarkan uji normalitas awal, data awal penelitian yang berasal dari nilai Pretest siswa adalah berdistribusi normal. Hal tersebut dibuktikan dengan hasil $L_{\text {hitung }}$ sebesar 0,99 sedangkan $L_{\text {tabel }}=0,195$. Berarti $\mathrm{L}_{\text {hitung }}$ 0,99<0,195 Ltabel. Rata-rata hasil Pretest yang diperoleh masih rendah dikarenakan proses pembelajaran yang berlangsung bersifat monoton. Belum digunakannya model dan media pembelajaran sehingga siswa cenderung kurang bersemangat untuk mengikuti pembelajaran.

Data akhir penelitian menggunakan data dari nilai Posttest siswa yaitu untuk mengetahui hasil belajar siswa setelah diberi perlakuan. Berdasarkan uji normalitas, data akhir penelitian dari nilai Posttest adalah berdistribusi normal. Hal tersebut dibuktikan dengan $\mathrm{L}_{\text {hitung }} 0,98<0,190$ Ltabel maka $\mathrm{H}_{0}$ diterima. Pada analisis akhir menggunakan uji t diperoleh hasil $t_{\text {hitung }}$ sebesar 139,45 sedangkan $t_{\text {tabel }} 2,09$ dengan $\mathrm{db}$ $=\mathrm{N}-1=20-1=19$, dan taraf signifikan 0,05. Karena $\mathrm{t}_{\text {hitung }}>\mathrm{t}_{\text {tabel }}$ yaitu 139,45>2,09 maka $\mathrm{H}_{0}$ ditolak dan $\mathrm{H}_{\mathrm{a}}$ diterima. Sehingga dapat dikatakan bahwa model pembelajaran Teams Game Tournament dengan media Dakonmatika berpengaruh terhadap hasil belajar siswa kelas IV SDN 01 Candi Semarang.

Berdasarkan uraian di atas dapat diketahui bahwa pembelajaran dengan menggunakan model pembelajaran Teams Game Tournament dengan media Dakonmatika berpengaruh terhadap hasil belajar siswa. Hasil penelitian menunjukkan bahwa penggunaan model Teams Game Tournament dengan media Dakonmatika juga membantu guru dalam mengelola kelas selama pembelajaran berlangsung. Hal ini dikarenakan siswa lebih tertarik, merasa senang serta dapat mendukung dan membantu keaktifan siswa selama proses pembelajaran.

Hal ini menunjukkan bahwa model Teams Game Tournament dengan media Dakonmatika berpengaruh terhadap hasil belajar siswa kelas IV khususnya pada mata pelajaran Matematika materi FPB \& KPK. Selain itu, dari hasil nilai Posttest menunjukkan bahwa hasil belajar siswa meningkat dari sebelumnya yaitu nilai Pretest.

Dikemukakan juga oleh Hamalik dalam Arsyad (2014: 19) bahwa pemakaian media pembelajaran dapat membangkitkan keinginan dan minat yang baru, membangkitkan motivasi dan rangsangan kegiatan belajar, dan bahkan membawa pengaruh-pengaruh psikologis terhadap siswa. Kekuatan Dakonmatika untuk mempengaruhi pikiran siswa terletak pada keseriusan dan ketelitian siswa menjalankan Dakonmatika untuk menemukan jawaban dari soal FPB \& KPK.

Media Dakonmatika memudahkan siswa untuk memahami apa yang dimaksudkan oleh guru ketika menyampaiakan materi pembelajaran, siswa cepat tanggap atas materi yang disampaikan karena diiringi dengan permainan yang dimana siswa ikut memeragakan jalannya Dakonmatika. Siswa lebih berkonsentrasi dan merasa asyik karena tugas yang diberikan oleh guru berkaitan dengan permainan mereka sehari-sehari. Menarik bagi siswa dikarenakan melalui visual dalam bentuk permainan dakon, sehingga siswa akan lebih aktif dan hasil belajar semakin meningkat.

Setelah dilakukan perlakuan, peneliti memberikan Posttest untuk mengetahui hasil belajar siswa setelah menggunakan model pembelajaran Teams Game Tournament dengan media Dakonmatika. Peneliti membandingkan hasil belajar dari nilai Pretest sebagai data awal dan nilai Posttest sebagai data nilai 
akhir. Nilai Pretest merupakan hasil belajar dari pembelajaran yang sebelum menggunakan model pembelajaran Teams Game Tournament dengan media Dakonmatika, sedangkan nilai Posttest merupakan hasil belajar dari pembelajaran yang setelah menggunakan model pembelajaran Teams Game Tournament dengan media Dakonmatika. Setelah diberikan perlakuan menggunakan model pembelajaran Teams Game Tournament dengan media Dakonmatika diperoleh nilai rata-rata hasil belajar pada Posttest meningkat dibandingkan pada nilai rata-rata hasil belajar pada Pretest. Pada saat Pretest didapatkan nilai rata-rata sebesar 40, sedangkan setelah diberikan perlakuan dengan menggunakan model pembelajaran Teams Game Tournament dengan media Dakonmatika didapatkan nilai rata-rata Posttest sebesar 78. Dengan demikian terjadi peningkatan nilai dari sebelum dan setelah menggunakan model pembelajaran Teams Game Tournament dengan media Dakonmatika.

Pada pelaksanaan penelitian menggunakan model pembelajaran Teams Game Tournament dengan media Dakonmatika terdapat beberapa kendala yang dialami oleh peneliti.Salah satu kendala yang dialami oleh peneliti yaitu siswa yang belum terbiasa dengan menggunakan model pembelajaran baru membuat suasana pada pertemuan pertama menjadi kurang berpengaruh. Tetapi hal tersebut dapat diperbaiki pada pertemuan kedua dan ketiga dengan menjelaskan lebih rinci kepada siswa dan siswa mulai terbiasa dengan pembelajaran menggunakan model pembelajaran Teams Game Tournament dengan media Dakonmatika sehingga suasana pembelajaran dapat berpengaruh baik terhadap siswa.

\section{Simpulan dan Saran}

Berdasarkan hasil penelitian maka dapat disimpulkan bahwa model pembelajaran Teams Game Tournament dengan media Dakonmatika berpengaruh terhadap hasil belajar Matematika materi FPB \& KPK siswa kelas IV SDN 01 Candi Semarang. Hal ini dapat dilihat dari hasil nilai perbedaan rata-rata uji $t$, nilai rata-rata Posttest lebih tinggi dari hasil nilai rata-rata Pretest. Dimana nilai rata-rata Pretest adalah 40,8 sedangkan nilai rata-rata Posttest adalah 78. Dan dapat dilihat juga dari uji $N$ Gain, peneliti mendapatkan hasil peningkatan 0,63 dengan keterangan sedang.

Beradsarkan kesimpulan di atas, saran yang dapat peneliti berikan sehubungan dengan hasil penelitian ini adalah model Teams Game Tournament dengan media Dakonmatika bisa digunakan sebagai variasi pembelajaran yang dapat membuat siswa tidak jenuh atau merasa bosan melainkan merasa senang mengikuti pembelajaran Matematika, sehingga materi yang disampaikan dapat diserap dengan baik dan hasil belajar siswa dapat meningkat diatas kriteria ketuntasan minimal yang sudah ditentukan.

\section{Daftar Rujukan}

Arikunto, Suharsimi. 2007. Prosedur Penelitian Suatu Pendekatan Praktik. Jakarta: Rineka Cipta.

Arikunto, Suharsimi. 2013. Dasar-Dasar Evaluasi Pendidikan. Jakarta: Bumi Aksara.

Arikunto, Suharsimi. 2014. Prosedur Penelitian Suatu Pendekatan Praktik. Jakarta: Rineka Cipta.

Arikunto, Suharsimi. 2015. Dasar-dasar Evaluasi Pendidikan. Jakarta: Bumi Aksara.

Arsyad, Azhar. 2014. Media Pembelajaran. Jakarta: PT RajaGrafindo Persada.

Arsyad, Azhar. 2016. Media Pembelajaran. Jakarta: PT RajaGrafindo Persada.

A'yuningsih, D. Q., Suardana, I. N., \& Suwenten, I. M. (2017). Penerapan Model Pembelajaran Kooperatif Tipe TGT (Teams Games Tournament) Untuk Meningkatkan Motivasi Dan Hasil Belajar Peserta Didik. Jurnal Pendidikan Kimia Indonesia, 1(2), 37-47.

Dimiyati dan Mudjiono. 2010. Belajar Dan Pembelajaran. Jakarta: PT Rineka Cipta.

Hamalik, Oemar. 2009. Proses Belajar Mengajar. Jakarta: PT Bumi Aksara.

Harjoko. 2014. "Meningkatkan Hasil Belajar Matematika Melalui Penerapan Model Pembelajaran Kooperatif Tipe TGT (Teams Game Tournament) Pada Siswa Kelas V SD N Kedungjambal 02 KAB.Sukoharjo Tahun Ajaran 2013/2014". Skripsi: Universitas Negeri Yogyakarta.

Heruman. 2014. Model Pembelajaran Matematika Di Sekolah Dasar. Bandung: PT Remaja Rosdakarya. 
Hidayat, Asep. 2016. Pengaruh Penggunaan Alat Peraga Dakon Matematika (DAKOTA) Terhadap Hasil Belajar Matematika Siswa. Skripsi: UIN Syarif Hidayatullah Jakarta.

Huda, Miftahul. 2014. Model-Model Pengajaran Dan Pembelajaran. Yogyakarta: Pustaka Pelajar.

Indriani, Dias Septi. 2014. Keefektifan Model Think Pair Share Terhadap Aktivitas Dan Hasil Belajar IPS. Journal Of Elementary Education. 3(2) (2014).

Peraturan Pemerintah. 2005. Nomor 19 Tahun 2005tentang Standar Nasional Pendidikan.

Permendiknas. 2003. UU RI No. 20 tahun 2003 tentang Sistem Pendidikan Nasional.

Purwanto, M Ngalim. 2003. Ilmu Pendidikan Teoritis Dan Praktis. Bandung: PT Remaja Rosdakarya.

Roshayanti, Hayat dan Prima. 2013. Model Pembelajaran Sains Dengan Permainan Dakon Untuk Mengembangkan Karakter Siswa. Prosiding UPGRIS.

Rusman. 2014. Model-Model Pembelajaran. Jakarta: PT RajaGrafindo Persada.

Shoimin, Aris. 2014. 68 Model Pembelajaran Inovatif Dalam Kurikulum 2013. Yogyakarta: Ar-Ruzz Media.

Siregar, Evelin, dan Nara, Hartini. 2011. Teori Belajar Dan Pembelajaran. Bogor: Ghalia Indonesia.

Slameto.2003. Belajar Dan Faktor-Faktor Yang Mempengaruhinya.Jakarta: PT Rineka Cipta.

Sugiyono. 2015. Metode Penelitian Pendidikan (Pendekatan Kuantitatif, Kualitatif, Dan R\&D). Bandung: Alfabeta CV.

Sukmadinata, Nana Syaodih. 2009. Landasan Psikologi Proses Pendidikan.Bandung: PT Remaja Rosdakarya.

Suwangsih, Erna, dan Tiurlina. 2006. Model Pembelajaran Matematika. Bandung: UPI Press.

Trianto. 2007. Model-Model Pembelajaran Inovatif Berorientasi Kontruktivistik. Jakarta: Prestasi Pustaka

Widodo. 2013. Peningkatan Aktivitas Belajar Dan Hasil Belajar Siswa Dengan Metode Problem Based Learning Pada Siswa Kelas Viia Mts Negeri Donomulyo Kulon Progo Tahun Pelajaran 2012/2013 . Jurnal Fisika Indonesia No: 49, Vol XVII, Edisi April 2013 